Review

\title{
Heavy Metals in Crop Plants: Transport and Redistribution Processes on the Whole Plant Level
}

\author{
Valérie Page and Urs Feller * \\ Institute of Plant Sciences, University of Bern, Bern 3012, Switzerland; \\ E-Mail: valerie_page1@yahoo.fr
}

* Author to whom correspondence should be addressed; E-Mail: urs.feller@ips.unibe.ch;

Tel./Fax: +41-31-302-2109.

Academic Editor: Gareth Norton

Received: 25 June 2015 / Accepted: 1 September 2015 / Published: 9 September 2015

\begin{abstract}
Copper, zinc, manganese, iron, nickel and molybdenum are essential micronutrients for plants. However, when present in excess they may damage the plant or decrease the quality of harvested plant products. Some other heavy metals such as cadmium, lead or mercury are not needed by plants and represent pollutants. The uptake into the roots, the loading into the xylem, the acropetal transport to the shoot with the transpiration stream and the further redistribution in the phloem are crucial for the distribution in aerial plant parts. This review is focused on long-distance transport of heavy metals via xylem and phloem and on interactions between the two transport systems. Phloem transport is the basis for the redistribution within the shoot and for the accumulation in fruits and seeds. Solutes may be transferred from the xylem to the phloem (e.g., in the small bundles in stems of cereals, in minor leaf veins). Nickel is highly phloem-mobile and directed to expanding plant parts. Zinc and to a lesser degree also cadmium are also mobile in the phloem and accumulate in meristems (root tips, shoot apex, axillary buds). Iron and manganese are characterized by poor phloem mobility and are retained in older leaves.
\end{abstract}

Keywords: heavy metals; micronutrients; pollutants; transport; xylem; phloem; redistribution 


\section{Heavy Metals: Micronutrients or Pollutants?}

Several heavy metals (e.g., $\mathrm{Fe}, \mathrm{Mn}, \mathrm{Cu}, \mathrm{Zn}, \mathrm{Ni}$, and $\mathrm{Mo}$ ) are required in traces as micronutrients by plants [1-3], while others (e.g., $\mathrm{Cd}, \mathrm{Cr}, \mathrm{Hg}$, and $\mathrm{Pb}$ ) are known as pollutants [4-12]. Major functions of heavy metals in plant metabolism are based on their involvement in oxidation/reduction processes $[1,2,13]$. Fe is essential as central ion in heme proteins (e.g., in cytochromes, nitrate reductase, catalase, and peroxidase), in siroheme proteins (e.g., nitrite reductase and sulfite reductase), in iron-sulfur proteins (e.g., ferredoxin) and in other iron-containing proteins (e.g., lipoxygenases) [1,2,13-16]. Ferritin is located in plastids and represents important intracellular storage form for $\mathrm{Fe}$ [17-19]. Mn is essential for the oxygen evolution in photosystem II and for a series of enzymatic reactions (e.g., phosphoenolpyruvate carboxykinase, and superoxide dismutase) $[1,2,13,20-22] . \mathrm{Cu}$ is present in the plastidial plastocyanin, in the mitochondrial cytochrome $\mathrm{c}$ oxidase, in $\mathrm{Cu}-\mathrm{Zn}$ superoxide dismutase as well as in a series of other proteins [1,2,13,23-26]. Zn is essential for several enzymes (e.g., metalloproteinase, carbonic anhydrase, and $\mathrm{Cu}-\mathrm{Zn}$ superoxide dismutase) [1,2,13,26-30]. Ni is known for its involvement in urease activity [1,2,13,14,31-34]. Mo (present in the soil solution as molybdate anion) is part of the molybdenum cofactor, which is required for nitrate reductase or xanthine dehydrogenase activity [1,2,13,14,35-37]. Co is an interesting element in this context, since it is not required by the higher plant itself, but is essential for the microorganisms involved in symbiotic nitrogen fixation $[2,38,39]$. Even those heavy metals required as micronutrients by all plants may become pollutants at elevated levels [2,40,41]. This review is focused on long-distance transport of heavy metals in crop plants, since the redistribution via xylem and phloem is important for the micronutrient supply of various plant parts and also for the accumulation of undesirably large quantities damaging the plant or negatively influencing the quality of harvested plant products.

The importance of heavy metal homeostasis in plants is illustrated in Figure 1. Heavy metals present at elevated levels may cause an increased production of reactive oxygen species (ROS) in plant cells on one hand [42-51] and may be involved in the enzymatic detoxification of ROS on the other hand [2,3,42,52-54]. Stresses (e.g., drought, heat and high light intensity) may also cause an accumulation of ROS and of ROS-damaged cell constituents [54,55]. These findings underline the importance of heavy metal homeostasis for plant cells. Several forms of superoxide dismutases are present in plants: $\mathrm{Cu} / \mathrm{Zn}$ superoxide dismutases (usually present under several forms) were reported to be present in various subcellular compartments, while Mn superoxide dismutase isoforms were localized in the mitochondria and Fe superoxide dismutase was reported to be a plastidial enzyme [1,2,54]. Especially Mn superoxide dismutase activity was found to be increased under drought stress [54]. 


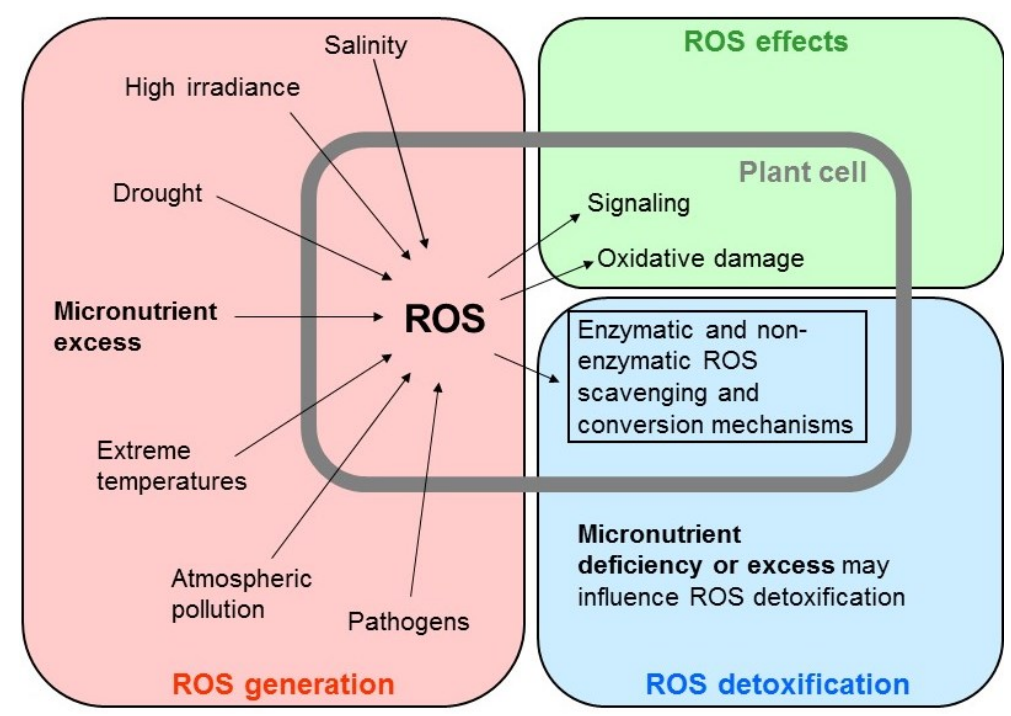

Figure 1. Involvement of micronutrients (e.g., Fe, Mn, $\mathrm{Zn}, \mathrm{Cu}$ and $\mathrm{Ni}$ ) in the generation and detoxification of ROS in plant cells under abiotic and biotic stress. Micronutrient deficiency and excess influence ROS levels and as a consequence damages caused by them.

\section{Transport with the Transpiration Stream in the Xylem}

Numerous processes in the soil, which are not subject of this review, may influence heavy metal solubility and as a consequence the availability for plants [2]. In some cases, heavy metals (e.g., Co, Cr, and $\mathrm{Fe}$ ) are retained in the roots and only a minor portion reaches the shoot [56-61]. This retention can be due to insolubilization (e.g., at the root surface and in the root apoplast) [56,57] or to a compartmentation in cells avoiding the release to the xylem [58,59]. Oxygen released from the roots may cause oxidation and insolubilization of iron in the root apoplast of rice grown in waterlogged soil [57].

A strong retention in the roots was detected in wheat and lupin for Co $[60,61]$ and in lupin also for Cd [60]. These elements were present in soluble form, but only a minor portion reached the vascular cylinder suggesting that compartmentation played a major role [58-60]. The abundance of ligands and the formation of heavy metal complexes with organic acids [62,63], with phytochelatin [64] or with nicotianamine [65] were found to be important for the retention in the roots. Good evidence was presented for the involvement of Ni-histidine complexes in the vacuolar compartmentation of $\mathrm{Ni}$ and as a consequence in the retention of this heavy metal in roots [59]. A heavy metal ATPase was suggested to be involved in $\mathrm{Cd}$ accumulation in vacuoles of root cells causing $\mathrm{Cd}$ retention in roots and decreasing the transport to the shoot [66].

Heavy metals are transported with the transpiration stream in the xylem from the roots to transpiring shoot parts (e.g., photosynthesizing leaves) $[60,61,67]$. After the release into the root xylem, free or chelated ions flow with the xylem sap upwards (Figure 2). Important for the concentration of heavy metals in the transpiration stream are xylem loading in the roots, interactions with cell walls during acropetal transport and selective removal from the xylem sap $[65,66,68,69]$. If there would be no further redistribution, the heavy metals would accumulate primarily in photosynthetically active (transpiring) leaves. Such an accumulation with no or only a minor redistribution was observed for the micronutrient $\mathrm{Mn}$ as well as for the macronutrient $\mathrm{Ca}$ and to a minor extent for Fe (Figures 2 and 3) [2,67-70]. Although 
the xylem vessels are dead, membranes of living cells around the vessels allow a selective removal of ions from the xylem sap $[68,69]$.

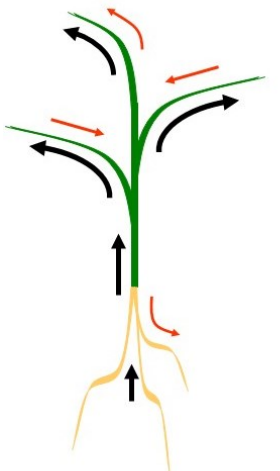

$\mathrm{Zn}$

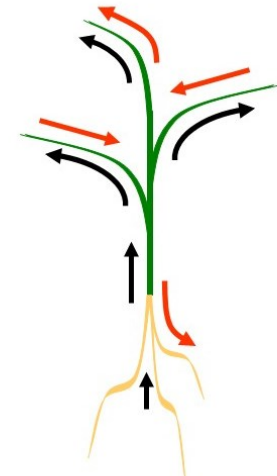

$\mathrm{Ni}$

$$
\begin{aligned}
& \longleftarrow \text { Xylem transport } \\
& \text { Phloem transport }
\end{aligned}
$$

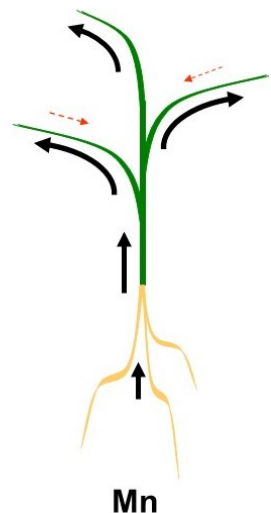

Figure 2. Xylem and phloem transport in the intact plant. Zn, Ni and $\mathrm{Mn}$ are readily transported via xylem to the shoot. Mn is essentially immobile in phloem, while Ni is rapidly redistributed to the youngest (expanding) plant parts and $\mathrm{Zn}$ is more slowly redistributed via the phloem (accumulation in meristems, but also well mobile in the phloem).

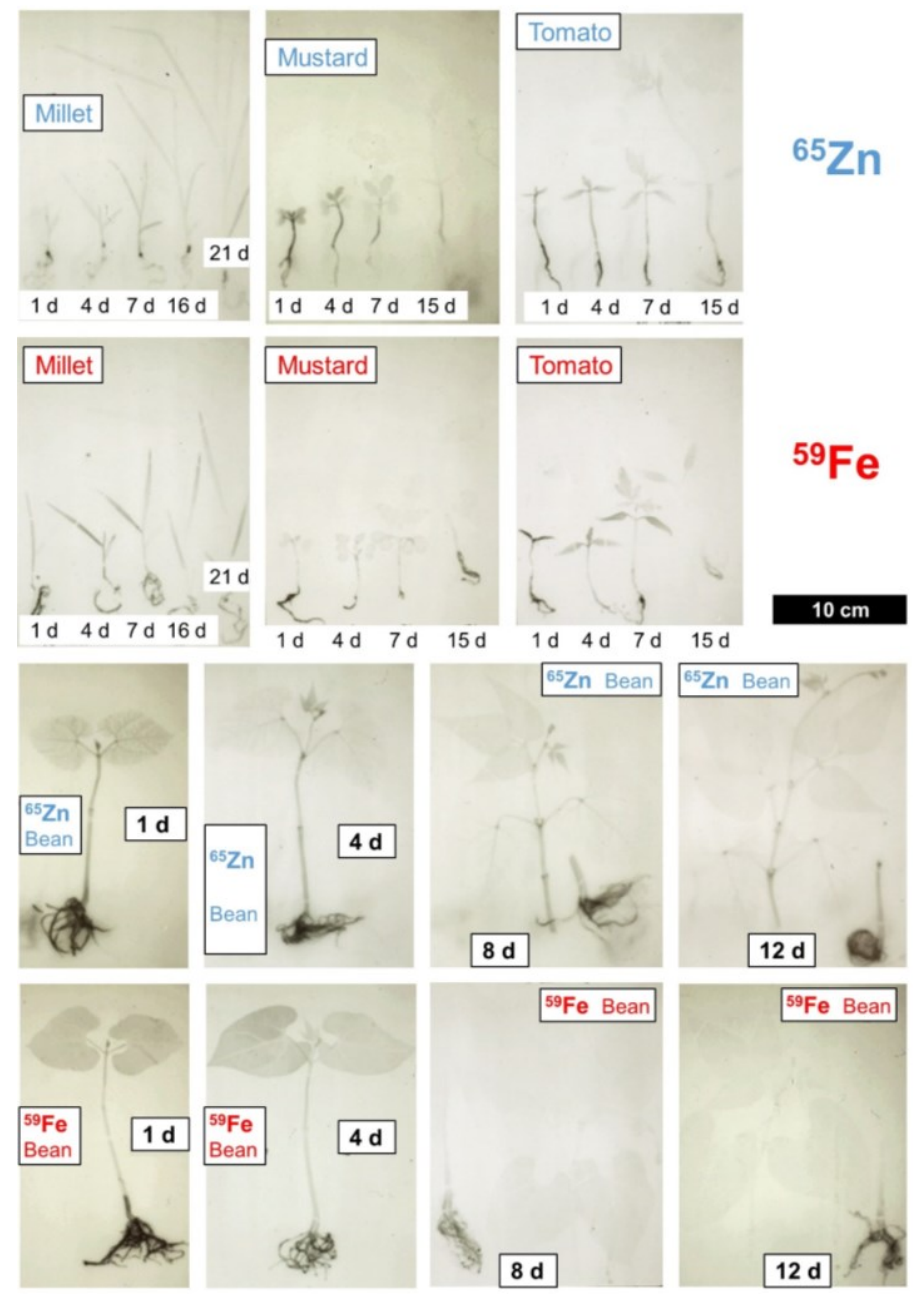


Figure 3. Autoradiographs documenting ${ }^{65} \mathrm{Zn}$ and ${ }^{59} \mathrm{Fe}$ distribution and redistribution in millet, mustard, tomato and dwarf bean. Young plants were labeled for one day with nutrient solution containing ${ }^{65} \mathrm{Zn}$ or ${ }^{59} \mathrm{Fe}$. The roots of the labeled plants were rinsed several times with unlabeled nutrient solution and then incubated for up to 12 days (bean), 15 days (mustard, tomato) or 21 days (millet). Plants collected throughout the incubation period were dried, fixed on cardboard and then exposed in darkness to an X-ray film. The relative distribution of the label in a plant must be considered and not the absolute label content in a particular plant part, since initial labeling was not identical.

\section{Redistribution via the Phloem}

The symplastic transport via the phloem allows a redistribution of nutrients, assimilates and pollutants within the plants and depends on the actual source/sink network (Figure 2) [71-73]. Phloem mobility of heavy metals varies in a wide range. $\mathrm{Ni}$ is highly phloem-mobile and can be repeatedly redistributed in crop plants throughout vegetative growth and the reproductive phase (Figure 2) [60,61,69]. $\mathrm{Zn}$ is also mobile in plants and can be transported via the phloem to growing plant parts (Figure 2) $[60,61,68,69]$. Cd (a pollutant and not a nutrient for plants) is less phloem-mobile than $\mathrm{Zn}$, but it is also to some extent redistributed via the phloem [60,61,69]. An extremely poor redistribution via the phloem was found for $\mathrm{Mn}$ and Fe $[60,61,69]$. Although these two elements are micronutrients, they are not easily transported from mature organs to major sinks (e.g., developing roots, emerging leaves, maturing fruits). Distribution patterns for several heavy metals are summarized in Figure 4. Approaches to identify redistribution processes via the phloem include balance sheets for contents in various organs $[60,61,70,74]$, introduction of radiolabeled heavy metals into a defined leaf via a flap [69] and phloem interruption (e.g., by steam-girdling) [68,69,74].

Source strength and sink strength are important for the direction and the velocity of phloem sap flow, while phloem loading is essential for the transported compounds [71-73]. The delivery through plasmodesmata in symplastic phloem loaders and the uptake through the membrane of the sieve tube-companion cell complex are crucial for the composition of the phloem sap [71-73]. Within the shoot, heavy metals can be redistributed from senescing leaves via the phloem to sinks (e.g., growing vegetative parts and maturing fruits). Another possibility is the transfer to the phloem before the xylem sap reaches mesophyll cells [2,68,69]. Several types of metal-binding compounds including nicotianamine and phytochelatins were reported to be relevant for the transport of heavy metals in the phloem [75-77]. A transporter for the copper-nicotianamine complex was found to be located in the phloem of rice leaves and was proposed to be important for the translocation of $\mathrm{Cu}$ from leaves to developing organs and maturing seeds [78]. 


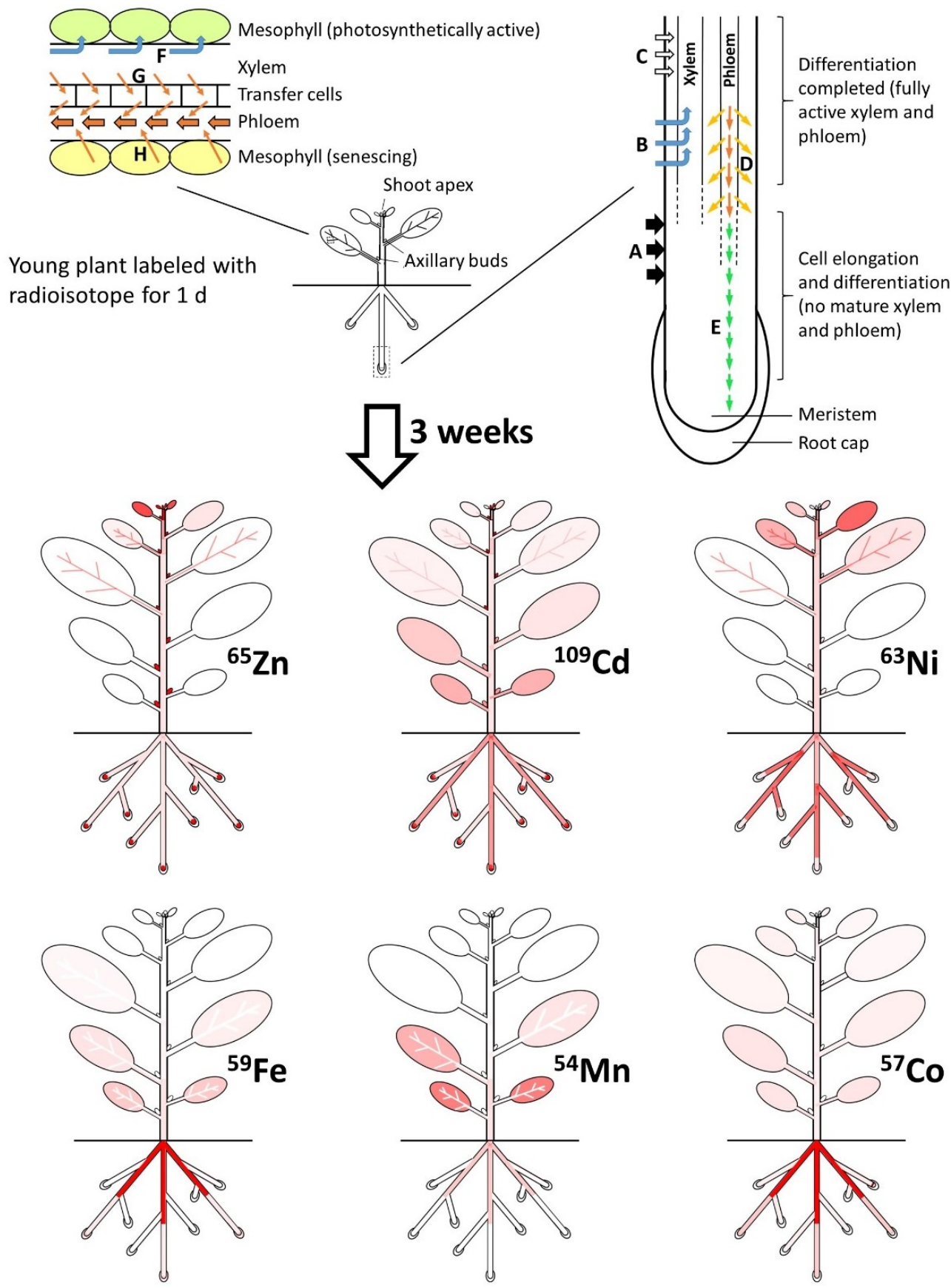

Figure 4. Scheme summarizing the processes involved in the distribution and redistribution of heavy metals in plants. The relative distribution patterns (red color) of ${ }^{65} \mathrm{Zn}$, ${ }^{109} \mathrm{Cd},{ }^{63} \mathrm{Ni},{ }^{59} \mathrm{Fe},{ }^{54} \mathrm{Mn}$ and ${ }^{57} \mathrm{Co}$ are based on autoradiographs with various plant species emphasizing important findings. The following processes are involved in generating these radionuclide-specific distribution patterns: insolubilization at the roots surface and in the root apoplast (A); uptake and loading into the root xylem (B); uptake and retention in root cells (C); basipetal transport to the roots via the phloem (D); cell-to-cell transport in meristems and regions without functional phloem $(\mathbf{E})$; transport with the transpiration stream in the xylem to mesophyll cells (F); transfer from xylem to phloem via transfer cells in small bundles $(\mathbf{G})$; and remobilization from senescing leaves and transport to sinks via the phloem (H). 
The redistribution from expanded leaves to sinks represents besides the flux from the roots to the shoot an additional control mechanism for the heavy metal contents in emerging organs and maturing fruits and seeds $[68,70,74,79]$. Fe and $\mathrm{Mn}$ are reduced in waterlogged soil to the well water-soluble $\mathrm{Fe}^{++}$ and $\mathrm{Mn}^{++}$ions increasing for these two elements the concentration in the soil solution [70]. As a consequence, higher Fe and Mn contents can be detected in wheat shoots under such conditions [70]. The contents are drastically increased in leaves and glumes, while the grains are far less affected [70]. These findings indicate that the control of redistribution processes via the phloem is important for the composition of harvested grains [70]. Elevated concentrations of $\mathrm{Zn}, \mathrm{Ni}$, Co or $\mathrm{Cd}$ cause somewhat increased contents in wheat grains, but leaves and glumes are far more affected suggesting again a control of heavy metal delivery to the grains via the phloem $[68,80,81]$.

\section{Xylem/Phloem Interactions}

Xylem and phloem are two different long-distance transport systems with different properties. Functional xylem and phloem are often separated by a cambium and not yet fully differentiated elements (e.g., in stems of dicotyledonous plants or in gymnosperms) [82]. Rays may allow a xylem-phloem exchange of solutes [84]. Functional xylem and phloem elements are close together and may interact more directly in the small stem bundles of cereals or in minor leaf veins without cambium and without formation of secondary vascular tissues $[82,83]$. This arrangement allows the selective transfer of solutes from the xylem to the phloem [2,84]. Transfer cells with a proliferated cell surface are presumably key players for the selective xylem-to-phloem transfer of heavy metals and other solutes (Figure 4) $[2,84,85]$. From steam-girdling experiments and heavy metal balance sheets it became evident that in the stem of wheat some heavy metals (e.g., the micronutrients $\mathrm{Zn}$ and $\mathrm{Ni}$ and the pollutant $\mathrm{Cd}$ ) are transferred from the xylem to the phloem, while other heavy metals (e.g., the micronutrient $\mathrm{Mn}$ or $\mathrm{Fe}$ ) are not or only much less efficiently loaded into the phloem $[68,69,74,80]$. Since the transfer of ${ }^{65} \mathrm{Zn}$ from the xylem to the phloem was also observed in the wheat peduncle without node, it can be concluded that this type of phloem loading occurs in the small bundles in internodes and that the node is not a prerequisite [68]. Such a selective xylem-to-phloem transfer (e.g., in the peduncle of wheat or in minor veins of lupin) allows a channeling of solutes to the maturing grains/seeds. In leaves of legumes labeled via the roots for a short period (e.g., for one day) and then incubated for several days in unlabeled medium clear differences between the labeling patterns with ${ }^{65} \mathrm{Zn}$ and ${ }^{59} \mathrm{Fe}$ can be observed (Figures 3 and 4). The veins in bean leaves are strongly labeled after ${ }^{65} \mathrm{Zn}$ introduction, while other leaf cells contain far less ${ }^{65} \mathrm{Zn}$. This pattern can be explained by the transfer from the rapidly flowing xylem to the more slowly flowing phloem (Figure 4). In contrast, ${ }^{59} \mathrm{Fe}$ is mainly present in interveinal regions, while the veins are far less labeled (Figures 3 and 4). Such a labeling pattern can be explained by the flux with the transpiration stream to minor leaf veins followed by an accumulation in non-vascular tissues (Figure 4), as was proposed previously for some amino acids [84].

Some heavy metals (e.g., $\mathrm{Ni}, \mathrm{Zn}, \mathrm{Co}$, and $\mathrm{Cd}$ ) may be delivered to roots by basipetal transport in the phloem (Figure 4) [69]. Afterwards they may be partially loaded again into the xylem and flow upwards with the transpiration stream. ${ }^{63} \mathrm{Ni},{ }^{65} \mathrm{Zn}$ and ${ }^{109} \mathrm{Cd}$ are redistributed via the phloem and can be translocated to previously unlabeled roots and to newly formed leaves [60,61]. However, the distribution of ${ }^{63} \mathrm{Ni}$ differs from that of ${ }^{65} \mathrm{Zn}$ and ${ }^{109} \mathrm{Cd}[60,61,86]$. While ${ }^{63} \mathrm{Ni}$ accumulates in expanding leaves and 
in root parts behind the meristem, ${ }^{65} \mathrm{Zn}$ and ${ }^{109} \mathrm{Cd}$ strongly accumulate in root tips, apical shoot meristems and axillary buds $[60,61,86]$. This difference might be caused by a transport of ${ }^{63} \mathrm{Ni},{ }^{65} \mathrm{Zn}$ and ${ }^{109} \mathrm{Cd}$ via the phloem followed by an efficient cell-to-cell transport of ${ }^{65} \mathrm{Zn}$ and ${ }^{109} \mathrm{Cd}$ (but not of ${ }^{63} \mathrm{Ni}$ ) to the meristem through the not yet fully differentiated regions without a functional phloem $[60,61,86]$.

\section{Selective Accumulation of Heavy Metals in Harvested Plant Parts}

The contents of heavy metals in plant products for human nutrition or in fodder plants are important for the quality of the harvest [87-98]. It must be distinguished between seed/grain crops such as cereals or soybean and plants of which the whole shoot is harvested such as plants used for silage or grasslands. Good phloem mobility is a prerequisite for the redistribution of heavy metals from leaves to maturing seeds. When whole shoots are used for human or animal nutrition, the total content in the shoot is very important, while redistribution via the phloem is far less relevant. In contrast, phloem transport is highly relevant when only cereal grains or seeds of dicotyledenous plants are harvested.

In certain regions a sufficient supply of heavy metals for humans (e.g., $\mathrm{Fe}$ and $\mathrm{Zn}$ ) is an issue [87-91]. The uptake of heavy metals into the plants, the transport to the shoot and redistribution processes within the shoot are involved in controlling the contents in harvested products. Breeding is a key aspect in the context of biofortification of plant products with heavy metals to overcome deficiencies in humans and animals [88,90]. Furthermore, negative effects of antinutrients interfering with heavy metal availability (e.g., phytate, oxalate) must be considered when evaluating the bioavailability of essential heavy metals [90,91].

Elevated contents of heavy metals - especially of pollutants such as $\mathrm{Cd}, \mathrm{Cr}$ or $\mathrm{Pb}$ - can also decrease the quality of harvested plant products [92-98]. Undesirably high or even toxic levels are a rather local, but nevertheless an important problem. Low uptake rates for the pollutant(s), a slow root-to-shoot transfer and a minimized redistribution to harvested shoot parts is desirable for crops grown on polluted soil. Contaminated irrigation water, the use of sewage sludge for fertilization, the release of pollutants from industrial processes and an improved solubilization of some heavy metals under extreme climatic conditions (e.g., flooding) may cause undesirably high concentrations in plant products [93-98]. Even when the input of heavy metals in contaminated soil is drastically lowered, fields may still contain high heavy metal contents for decades. A cautious selection of crop species and varieties, optimized nutrient supply, and phytoremediation of the field may contribute to improve the situation.

\section{Relevance of Long-Distance Transport for Phytoremediation}

Hyperaccumulators of heavy metals are important for phytoremediation of polluted soils [99-101]. Such plants should have properties clearly differing from desirable properties of crop plants. Hyperaccumulators should efficiently take up heavy metals from the soil, should transport them to the shoot and not retain them in the belowground plant parts. Furthermore, they should tolerate high contents without showing symptoms of toxicity [99-104]. Cd, Co and Zn are efficiently transported from the roots to the shoot of the hyperaccumulator Solanum nigrum and are further redistributed within the shoot via the phloem [103]. Rapid uptake and release into the xylem are key properties of this species, while the redistribution via the phloem would be less important when whole shoots would be collected for phytoremediation [103]. 
Ligands were found to be important in hyperaccumulators for vacuolar sequestration and for the transport of heavy metals in the xylem $[59,62,65]$. Genetic engineering of the metabolism may lead to increased concentrations of ligands important for xylem loading and to decreased levels of ligands leading to vacuolar sequestration causing a retention of heavy metals in the roots $[59,62,65,105,106]$. Transporters for heavy metals or heavy metal complexes represent other targets for classical breeding and genetic engineering to improve properties of plants envisaged for phytoremediation [107,108].

\section{Conclusions}

Some translocators for heavy metals or heavy metal complexes are known, but we are far away from knowing the network of translocator proteins involved in the uptake into the roots, the subcellular distribution in roots and shoots, the release from the root symplast to the xylem, the uptake from the apoplast into leaf cells and the loading into the phloem for further redistribution $[78,109,110]$. A more complete picture of transporters for heavy metals is highly desirable and may serve as a basis for genotype selection and breeding. Genetic tools available nowadays will presumably allow a rapid progress in this field.

The chemical forms (e.g., chelating agents) in various subcellular compartments as well as during long-distance transport in xylem and phloem should be known in more detail. The availability of complexing agents in a plant cell may be relevant for the retention in the cell (e.g., transport across the tonoplast and storage in the vacuole), the transfer to neighbor cells through plasmodesmata and the release into the apoplast for xylem or phloem loading. Sensitive localization techniques for heavy metals and metabolic studies for ligand availability may serve as a basis for more detailed studies [59,62-66,71,78,111].

Often interactions between various biotic and/or abiotic stresses affect plant growth and the composition of the biomass [112,113]. High salt concentrations or climatic factors such as drought or heat should be considered in more detail in the context of global change.

It will be a challenge for agronomists and for plant breeders to select appropriate genotypes for a given environment and to breed new genotypes with desired properties [114,115]. The harvested plant parts as well as the utilization of the plant biomass and not only heavy metal availability in the soil or other environmental factors are relevant in this context. Biofortification depends on the accumulation of desired micronutrients and on avoiding high levels of undesired heavy metals in plant parts harvested for human or animal nutrition [88,91]. Selective redistribution and accumulation processes for various heavy metals are the basis for well-balanced contents and must be considered for agronomic strategies, including plant breeding, genotype selection and agronomic practices [88,91]. Criteria for seed crops, grassland plants and heavy metal hyperaccumulators differ considerably. This must be adequately considered in basic research as well as in agronomic applications and breeding programs.

\section{Acknowledgments}

The authors thank Franzsika von Lerber for providing the previously unpublished ${ }^{59} \mathrm{Fe}$ and ${ }^{65} \mathrm{Zn}$ autoradiographs with various plant species. Experimental work was supported by the Institute of Plant Sciences, University of Bern. 


\section{Author Contributions}

Valérie Page analyzed and reviewed heavy metal transport processes in cereals and legumes and contributed to writing the manuscript. Urs Feller analyzed and reviewed xylem-phloem interactions and heavy metal transport in hyperaccumulators and contributed to writing the manuscript.

\section{Conflicts of Interest}

The authors declare no conflict of interest.

\section{References}

1. Hänsch, R.; Mendel, R.R. Physiological functions of mineral micronutrients $(\mathrm{Cu}, \mathrm{Zn}, \mathrm{Mn}, \mathrm{Fe}, \mathrm{Ni}$, Mo, B, Cl). Curr. Opin. Plant Biol. 2009, 12, 259-266, doi:10.1016/j.pbi.2009.05.006.

2. Marschner, H. Mineral Nutrition of Higher Plants, 2nd ed.; Academic Press: London, UK, 1995, p. 38.

3. Grotz, N.; Guerinot, M.L. Molecular aspects of $\mathrm{Cu}, \mathrm{Fe}$ and $\mathrm{Zn}$ homeostasis in plants. Biochim. Biophys. Acta-Mol. Cell Res. 2006, 1763, 595-608, doi:10.1016/j.bbamcr.2006.05.014.

4. Prasad, M.N.V. Cadmium toxicity and tolerance in vascular plants. Environ. Exp. Bot. 1995, 35, 525-545, doi:10.1016/0098-8472(95)00024-0.

5. Pal, M.; Horvath, E.; Janda, T.; Paldi, E.; Szalai, G. Physiological changes and defense mechanisms induced by cadmium stress in maize. J. Plant Nutr. Soil Sci. 2006, 169, 239-246, doi:10.1002/jpln.200520573.

6. Liu, W.; Yang, Y.S. Li, P.J.; Zhou, Q.X.; Xie, L.J.; Han, Y.P. Risk assessment of cadmium-contaminated soil on plant DNA damage using RAPD and physiological indices. J. Hazard. Mater. 2009, 161, 878-883, doi:10.1016/j.jhazmat.2008.04.038.

7. Rascio, N.; Vecchia, F.D.; La Rocca, N.; Barbato, R.; Pagliano, C.; Raviolo, M.; Gonnelli, C.; Gabbrielli, R. Metal accumulation and damage in rice ( $c v$. Vialone nano) seedlings exposed to cadmium. Environ. Exp. Bot. 2008, 62, 267-278, doi:10.1016/j.envexpbot.2007.09.002.

8. Singh, S.; Sinha, S.; Saxena, R.; Pandey, K.; Bhatt, K. Translocation of metals and its effects in the tomato plants grown on various amendments of tannery waste: Evidence for involvement of antioxidants. Chemosphere 2004, 57, 91-99, doi:10.1016/j.chemosphere.2004.04.041.

9. Zhou, Z.S.; Zhao, S.; Wang, S.J.; Yang, Z.M. Biological detection and analysis of mercury toxicity to alfalfa (Medicago sativa) plants. Chemosphere 2008, 70, 1500-1509, doi:10.1016/j.chemosphere.2007.08.028.

10. Cenkci, S.; Cigerci, I.H.; Yildiz, M.; Ozay, C.; Bozdag, A.; Terzi, H. Lead contamination reduces chlorophyll biosynthesis and genomic template stability in Brassica rapa L. Environ. Exp. Bot. 2010, 67, 467-473, doi:10.1016/j.envexpbot.2009.10.001.

11. Pinho, S.; Ladeiro, B. Phytotoxicity by lead as heavy metal focus on oxidative stress. J. Bot. 2012, 2012, doi:10.1155/2012/369572.

12. Sharma, D.C.; Sharma, C.; Tripathi, R.D. Phytotoxic lesions of chromium in maize. Chemosphere 2003, 51, 63-68, doi:10.1016/S0045-6535(01)00325-3. 
13. Welch, R.M. Micronutrient nutrition of plants. Crit. Rev. Plant Sci. 1995, 14, 49-82, doi:10.1080/713608066.

14. Campbell, W.H. Nitrate reductase structure, function and regulation: Bridging the gap between biochemistry and physiology. Annu. Rev. Plant Physiol. Plant Mol. Biol. 1999, 50, 277-303, doi:10.1146/annurev.arplant.50.1.277.

15. Prescott, A.G.; John, P. Dioxygenases: Molecular structure and role in plant metabolism. Annu. Rev. Plant Physiol. Plant Mol. Biol. 1996, 47, 245-271, doi:10.1146/annurev.arplant.47.1.245.

16. Siedow, J.N. Plant lipoxygenase-Structure and function. Annu. Rev. Plant Physiol. Plant Mol. Biol. 1991, 42, 145-188, doi:10.1146/annurev.arplant.42.1.145.

17. Briat, J.F.; Lobreaux, S. Iron transport and storage in plants. Trends Plant Sci. 1997, 2, 187-193, doi:10.1016/S1360-1385(97)85225-9.

18. Briat, J.F.; Lobreaux, S.; Grignon, N.; Vansuyt, G. Regulation of plant ferritin synthesis: How and why. Cell. Mol. Life Sci. 1999, 56, 155-166, doi:10.1007/s000180050014.

19. Ravet, K.; Touraine, B.; Boucherez, J., Briat, J.F.; Gaymard, F.; Cellier, F. Ferritins control interaction between iron homeostasis and oxidative stress in Arabidopsis. Plant J. 2009, 57, 400-412, doi:10.1111/j.1365-313X.2008.03698.x.

20. Lidon, F.C.; Barreiro, M.G.; Ramalho, J.C. Manganese accumulation in rice: Implications for photosynthetic functioning. J. Plant Physiol. 2004, 161, 1235-1244, doi:10.1016/j.jplph.2004.02.003.

21. Lanquar, V.; Ramos, M.S.; Lelievre, S.; Barbier-Brygoo, H.; Krieger-Liszkay, A.; Kramer, U.; Thomine, S. Export of vacuolar manganese by AtNRAMP3 and AtNRAMP4 is required for optimal photosynthesis and growth under manganese deficiency. Plant Physiol. 2010, 152, 1986-1999, doi:10.1104/pp.109.150946.

22. Filiz, E.; Tombuloglu, H. Genome-wide distribution of superoxide dismutase (SOD) gene families in Sorghum bicolor. Turk. J. Biol. 2015, 39, 49-59, doi:10.3906/biy-1403-9.

23. Yruela, I. Copper in plants: Acquisition, transport and interactions. Funct. Plant Biol. 2009, 36, 409-430, doi:10.1071/FP08288.

24. Redinbo, M.R.; Yeates, T.O.; Merchant, S. Plastocyanin-Structural and functional analysis. J. Bioenerg. Biomembr. 1994, 26, 49-66, doi:10.1007/BF00763219.

25. Bueno, P.; Varela, J.; Gimenezgallego, G.; Delrio, L.A. Peroxisomal copper,zinc-superoxide dismutase - Characterization of the isoenzyme from watermelon cotyledons. Plant Physiol. 1995, 108, 1151-1160, doi:10.1104/pp.108.3.1151.

26. Yruela, I. Transition metals in plant photosynthesis. Metallomics 2013, 5, 1090-1109, doi:10.1039/c3mt00086a.

27. Mishra, P.; Dixit, A.; Ray, M.; Sabat, S.C. Mechanistic study of CuZn-SOD from Ipomoea carnea mutated at dimer interface: Enhancement of peroxidase activity upon monomerization. Biochimie 2014, 97, 181-193, doi:10.1016/j.biochi.2013.10.014.

28. Hacisalihoglu, G.; Hart, J.J., Wang, Y.H.; Cakmak, I.; Kochian, L.V. Zinc efficiency is correlated with enhanced expression and activity of zinc-requiring enzymes in wheat. Plant Physiol. 2003, 131, 595-602, doi:10.1104/pp.011825. 
29. Delorme, V.G.R.; McCabe, P.F.; Kim, D.J.; Leaver, C.J. A matrix metalloproteinase gene is expressed at the boundary of senescence and programmed cell death in cucumber. Plant Physiol. 2000, 123, 917-927, doi:10.1104/pp.123.3.917.

30. Takatsuji, H. Zinc-finger transcription factors in plants. Cell. Mol. Life Sci. 1998, 54, 582-596, doi:10.1007/s000180050186.

31. Witte, C.P. Urea metabolism in plants. Plant Sci. 2011, 180, 431-438, doi:10.1016/j.plantsci.2010.11.010.

32. Sirko, A.; Brodzik, R. Plant ureases: Roles and regulation. Acta Biochim. Pol. 2000, 47, 1189-1195.

33. Polacco, J.C.; Freyermuth, S.K.; Gerendas, J.; Cianzio, S.R. Soybean genes involved in nickel insertion into urease. J. Exp. Bot. 1999, 50, 1149-1156, doi:10.1093/jexbot/50.336.1149.

34. Psaras, G.K.; Constantinidis, T.; Cotsopoulos, B.; Manetas, Y. Relative abundance of nickel in the leaf epidermis of eight hyperaccumulators: Evidence that the metal is excluded from both guard cells and trichomes. Ann. Bot. 2000, 86, 73-78, doi:10.1006/anbo.2000.1161.

35. Mendel, R.R.; Schwarz, G. Molybdoenzymes and molybdenum cofactor in plants. Crit. Rev. Plant Sci. 1999, 18, 33-69.

36. Mendel, R.R. Biology of the molybdenum cofactor. J. Exp. Bot. 2007, 58, 2289-2296, doi:10.1093/jxb/erm024.

37. Schwarz, G.; Boxer, D.H.; Mendel, R.R. Molybdenum cofactor biosynthesis-The plant protein Cnx1 binds molybdopterin with high affinity. J. Biol. Chem. 1997, 272, 26811-26814, doi:10.1074/jbc.272.43.26811.

38. O'Hara, G.W. Nutritional constraints on root nodule bacteria affecting symbiotic nitrogen fixation: A review. Aust. J. Exp. Agric. 2001, 41, 417-433, doi:10.1071/EA00087.

39. Jayakumar, K.; Vijayarengan, P.; Changxing, Z.; Gomathinayagam, M.; Jaleel, C.A. Soil applied cobalt alters the nodulation, leg-haemoglobin content and antioxidant status of Glycine max (L.) Merr. Colloid Surf. B-Biointerfaces 2008, 67, 272-275, doi:10.1016/j.colsurfb.2008.08.012.

40. Long, X.X.; Yang, X.E.; Ni, W.Z.; Ye, Z.Q.; He, Z.L.; Calvert, D.V.; Stoffella, J.P. Assessing zinc thresholds for phytotoxicity and potential dietary toxicity in selected vegetable crops. Commun. Soil Sci. Plant Anal. 2003, 34, 1421-1434, doi:10.1081/CSS-120020454.

41. Gupta, U.C.; Gupta, S.C. Trace element toxicity relationships to crop production and livestock and human health: Implications for management. Commun. Soil Sci. Plant Anal. 1998, 29, 1491-1522, doi:10.1080/00103629809370045.

42. Foyer, C.H.; Lelandais, M.; Kunert, K.J. Photooxidative stress in plants. Physiol. Plant. 1994, 92, 696-717, doi:10.1111/j.1399-3054.1994.tb03042.x.

43. Dat, J.; Vandenabeele, S.; Vranova, E.; Van Montagu, M.; Inze, D.; Van Breusegem, F. Dual action of the active oxygen species during plant stress responses. Cell. Mol. Life Sci. 2000, 57, 779-795, doi:10.1007/s000180050041.

44. Xu, X.Y.; Shi, G.X.; Wang, J.; Zhang, L.L.; Kang, Y.N. Copper-induced oxidative stress in Alternanthera philoxeroides callus. Plant Cell Tissue Organ Cult. 2011, 106, 243-251, doi:10.1007/s11240-010-9914-2. 
45. Rodriguez-Serrano, M.; Romero-Puertas, M.C.; Zabalza, A.; Corpas, F.J.; Bomet, M.; del Rio, L.A.; Sandalio, L.M. Cadmium effect on oxidative metabolism of pea (Pisum sativum L.) roots. Imaging of reactive oxygen species and nitric oxide accumulation in vivo. Plant Cell Environ. 2006, 29, 1532-1544, doi:10.1111/j.1365-3040.2006.01531.x.

46. Tewari, P.K.; Kumar, P; Sharma, P.N. Antioxidant responses to enhanced generation of superoxide anion radical and hydrogen peroxide in the copper-stressed mulberry plants. Planta 2006, 223, 1145-1153, doi:10.1007/s00425-005-0160-5.

47. Lei, Y.B.; Korpelainen, H.; Li, C.Y. Physiological and biochemical responses to high Mn concentrations in two contrasting Populus cathayana populations. Chemosphere 2007, 68, 686-694, doi:10.1016/j.chemosphere.2007.01.066.

48. Kumar, P.; Tewari, P.K.; Sharma, P.N. Modulation of copper toxicity-induced oxidative damage by excess supply of iron in maize plants. Plant Cell Rep. 2008, 27, 399-409, doi:10.1007/s00299-007-0453-1.

49. Gajewska, E.; Sklodowska, M. Effect of nickel on ROS content and antioxidative enzyme activities in wheat leaves. Biometals 2007, 20, 27-36, doi:10.1007/s10534-006-9011-5.

50. Shi, Q.H.; Zhu, Z.J.; Xu, M.; Qian, Q.Q.; Yu, J.Q. Effect of excess manganese on the antioxidant system in Cucumis sativus L. under two light intensities. Environ. Exp. Bot. 2006, 58, 197-205, doi:10.1016/j.envexpbot.2005.08.005.

51. Demirevska-Kepova, K.; Simova-Stoilova, L.; Stoyanova, Z.; Holzer, R.; Feller, U. Biochemical changes in barley plants after excessive supply of copper and manganese. Environ. Exp. Bot. 2004, 52, 253-266, doi:10.1016/j.envexpbot.2004.02.004.

52. Alscher, R.G.; Erturk, N.; Heath, L.S. Role of superoxide dismutases (SODs) in controlling oxidative stress in plants. J. Exp. Bot. 2002, 53, 1331-1341, doi:10.1093/jexbot/53.372.1331

53. Gill, S.S.; Tuteja, N. Reactive oxygen species and antioxidant machinery in abiotic stress tolerance in crop plants. Plant Physiol. Biochem. 2010, 48, 909-930, doi:10.1016/j.plaphy.2010.08.016.

54. Huseinova, I.M.; Aliyeva, D.R.; Aliyev, J.A. Subcellular localization and responses of superoxide dismutase isoforms in local wheat varieties subjected to continuous soil drought. Plant Physiol. Biochem. 2014, 81, 54-60, doi:10.1016/j.plaphy.2014.01.018.

55. Jiang, M.Y.; Zhang, J.H. Water stress-induced abscisic acid accumulation triggers the increased generation of reactive oxygen species and up-regulates the activities of antioxidant enzymes in maize leaves. J. Exp. Bot. 2002, 53, 2401-2410, doi:10.1093/jxb/erf090.

56. Kosegarten, H.; Koyro, H.W. Apoplastic accumulation of iron in the epidermis of maize (Zea mays) roots grown in calcareous soil. Physiol. Plant. 2001, 113, 515-522, doi:10.1034/j.1399-3054.2001.1130410.x.

57. Bravin, M.N.; Travassac, F.; Le Floch, M.; Hinsinger, P.; Garnier, J.M. Oxygen input controls the spatial and temporal dynamics of arsenic at the surface of a flooded paddy soil and in the rhizosphere of lowland rice (Oryza sativa L.): A microcosm study. Plant Soil 2008, 312, 207-218, doi:10.1007/s11104-007-9532-X.

58. Yang, X.; Li, T.Q.; Yang, J.C.; He, Z.L.; Lu, L.L.; Memg, F.H. Zinc compartmentation in root, transport into xylem, and absorption into leaf cells in the hyperaccumulating species of Sedum alfredii Hance. Planta 2006, 224, 185-195, doi:10.1007/s00425-005-0194-8. 
59. Richau, K.H.; Kozhevnikova, A.D.; Seregin, I.V.; Voojis, R.; Koevoets, P.L.M.; Snith, J.A.C.; Ivanov, V.B.; Schat, H. Chelation by histidine inhibits the vacuolar sequestration of nickel in roots of the hyperaccumulator Thlaspi caerulescens. New Phytol. 2009, 183, 106-116, doi:10.1111/j.1469-8137.2009.02826.x.

60. Page, V.; Weisskopf, L.; Feller, U. Heavy metals in white lupin: Uptake, root-to-shoot transfer and redistribution within the plant. New Phytol. 2006, 171, 329-341, doi:10.1111/j.1469-8137.2006.01756.x.

61. Page, V.; Feller, U. Selective transport of zinc, manganese, nickel, cobalt and cadmium in the root system and transfer to the leaves in young wheat plants. Ann. Bot. 2005, 96, 425-434, doi:10.1093/aob/mci189.

62. Bhatia, N.P.; Walsh, K.B.; Baker, A.J.M. Detection and quantification of ligands involved in nickel detoxification in a herbaceous Ni hyperaccumulator Stackhousia tryonii Bailey. J. Exp. Bot. 2005, 56, 1343-1349, doi:10.1093/jxb/eri135.

63. Sagardoy, R.; Morales, F.; Rellen-Alvarez, R.; Abadia, A.; Abadia, J.; Lopez-Millan, A.F. Carboxylate metabolism in sugar beet plants grown with excess Zn. J. Plant Physiol. 2011, 168, 730-733, doi:10.1016/j.jplph.2010.10.012.

64. Stolt, J.P.; Sneller, F.E.C.; Bryngellson, T.; Lundborg, T.; Schat, H. Phytochelatin and cadmium accumulation in wheat. Environ. Exp. Bot. 2003, 49, 21-28, doi:10.1016/S0098-8472(02)00045-X.

65. Mari, S.; Gendre, D.; Pianelli, K.; Ouerdane, L.; Lobinski, R.; Briat, J.-F. Root-to-shoot long-distance circulation of nicotianamine and nicotianamine-nickel chelates in the metal hyperaccumulator Thlaspi caerulescens. J. Exp. Bot. 2006, 57, 4111-4122, doi:10.1093/jxb/erl184.

66. Miyadate, H.; Adachi, S.; Hiraizumi, A.; Tezuka, K.; Nakazawa, N.; Kawamoto, T.; Katou, K.; Kodama, I.; Sakurai, K.; Takahashi, H.; et al. OsHMA3, a P-1B-type of ATPase affects root-to-shoot cadmium translocation in rice by mediating efflux into vacuoles. New Phytol. 2011, 189, 190-199, doi:10.1111/j.1469-8137.2010.03459.x.

67. Page, V.; Blösch, R.M.; Feller, U. Regulation of shoot growth, root development and manganese allocation in wheat (Triticum aestivum) genotypes by light intensity. Plant Growth Regul. 2012, 67, 209-215, doi:10.1007/s10725-012-9679-1.

68. Herren, T.; Feller, U. Transfer of zinc from xylem to phloem in the peduncle of wheat. J. Plant Nutr. 1994, 17, 1587-1598, doi:10.1080/01904169409364831.

69. Riesen, O.; Feller, U. Redistribution of nickel, cobalt, manganese, zinc and cadmium via the phloem in young and maturing wheat. J. Plant Nutr. 2005, 28, 421-430, doi:10.1081/PLN-20049153.

70. Stieger, P.A.; Feller, U. Nutrient accumulation and translocation in maturing wheat plants grown on waterlogged soil. Plant Soil 1994, 160, 87-95, doi:10.1007/BF00150349.

71. Van Bel, A.J.E. The phloem, a miracle of ingenuity. Plant Cell Environ. 2003, 26, 125-149, doi:10.1046/j.1365-3040.2003.00963.x.

72. Van Bel, A.J.E.; Gamalei, Y.V. Ecophysiology of phloem loading in source leaves. Plant Cell Environ. 1992, 15, 265-270.

73. Turgeon, R.; Wolf, S. Phloem transport: Cellular pathways and molecular trafficking. Annu. Rev. Plant Biol. 2009, 60, 207-221, doi:10.1146/annurev.arplant.043008.092045.

74. Zeller, S.; Feller, U. Long-distance transport of cobalt and nickel in maturing wheat. Eur. J. Agron. 1999, 10, 91-98, doi:10.1016/S1161-0301(98)00060-4. 
75. Stephan, U.W.; Scholz, G. Nicotianamine-Mediator of transport of iron in the phloem. Physiol. Plant. 1993, 88, 522-529, doi:10.1034/j.1399-3054.1993.880318.x.

76. Hazama, K.; Nagata, S.; Fujimori, T.; Yanagisawa, S.; Yoeneyama, T. Concentrations of metals and potential metal-binding compounds and speciation of $\mathrm{Cd}, \mathrm{Zn}$ and $\mathrm{Cu}$ in phloem and xylem saps from castor bean plants (Ricinus communis) treated with four levels of cadmium. Physiol. Plant. 2015, 154, 243-255, doi:10.1111/ppl.12309.

77. Mendoza-Cozatl, D.G.; Butko, E.; Springer, F.; Torpey, J.W.; Komives, E.A.; Kehr, J.; Schroeder, J.I. Identification of high levels of phytochelatins, glutathione and cadmium in the phloem sap of Brassica napus. A role for thiol-peptides in the long-distance transport of cadmium and the effect of cadmium on iron translocation. Plant J. 2008, 54, 249-259, doi:10.1111/j.1365-313X.2008.03410.x.

78. Zheng, L.Q.; Yamaji, N.; Yokosho, K.; Ma, J.F. YSL16 is a phloem-localized transporter of the copper-nicotianamine complex that is responsible for copper distribution in rice. Plant Cell 2012, 24, 3767-3782, doi:10.1105/tpc.112.103820.

79. Herren, T.; Feller, U. Effect of locally increased zinc contents on zinc transport from the flag leaf lamina to the maturing grains of wheat. J. Plant Nutr. 1996, 19, 379-387, doi:10.1080/01904169609365128.

80. Zeller, S.; Feller, U. Redistribution of cobalt and nickel in detached wheat shoots: effects of steam-girdling and of cobalt and nickel supply. Biol. Plant. 1998, 41, 427-434, doi: 10.1023/A:1001858728977.

81. Herren, T.; Feller, U. Influence of increased zinc levels on phloem transport in wheat shoots. J. Plant Physiol. 1997, 150, 228-231.

82. Fahn, A. Plant Anatomy, 3rd ed.; Pergamon Press: Oxford, UK, 1982; pp. 46-73.

83. Van Be, A.J.E. Xylem-phloem exchange via the rays-The undervalued route of transport. J. Exp. Bot. 1990, 41, 631-644, doi:10.1093/jxb/41.6.631.

84. McNeil, D.L.; Atkins, C.A.; Pate, J.S. Uptake and utilization of xylem-borne amino-compounds by shoot organs of a legume. Plant Physiol. 1979, 63, 1076-1081, doi:10.1104/pp.63.6.1076.

85. Offler, C.E.; McCurdy, D.W.; Patrick, J.W.; Talbot, M.J. Transfer cells: Cells specialized for a special purpose. Annu. Rev. Plant Biol. 2003, 54, 431-454, doi:10.1146/annurev.arplant.54.031902.134812.

86. Feller, U.; Anders, I.; Wei, S. Effects of PEG-Induced Water Deficit in Solanum nigrum on $\mathrm{Zn}$ and Ni Uptake and Translocation in Split Root Systems. Plants 2015, 4, 284-297, doi:10.3390/plants4020284.

87. Graham, R.D.; Knez, M.; Welch, R.M. How much nutritional iron deficiency in humans globally is due to an underlying zinc deficiency? Adv. Agron. 2012, 115, 1-40, doi:10.1016/B978-0-12-394276-0.00001-9.

88. Bouis, H.E.; Welch, R.M. Biofortification-A sustainable agricultural strategy for reducing micronutrient malnutrition in the global south. Crop Sci. 2010, 50, S20-S32, doi:10.2135/cropsci2009.09.0531.

89. Welch, R.M.; Graham, R.D. Agriculture: The real nexus for enhancing bioavailable micronutrients in food crops. J. Trace Elem. Med. Biol. 2005, 18, 299-307, doi:10.1016/j.jtemb.2005.03.001.

90. Welch, R.M.; Graham, R.D. Breeding for micronutrients in staple food crops from a human nutrition perspective. J. Exp. Bot. 2004, 55, 353-364, doi:10.1093/jxb/erh064. 
91. White, P.J.; Broadley, M.R. Biofortification of crops with seven mineral elements often lacking in human diets-Iron, zinc, copper, calcium, magnesium, selenium and iodine. New Phytol. 2009, 182, 49-84, doi:10.1111/j.1469-8137.2008.02738.x.

92. Khan, M.A.; Castro-Guerrero, N.; Medoza-Cozatl, D.G. Moving toward a precise nutrition: Preferential loading of seeds with essential nutrients over non-essential toxic elements. Front. Plant Sci. 2014, 5, 51, doi:10.3389/fpls.2014.00051.

93. Stasinos, S.; Nasopoulou, C.; Tsikrika, C.; Zabetakis, I. The bioaccumulation and physiological effects of heavy metals in carrots, onions, and potatoes and dietary implications for $\mathrm{Cr}$ and $\mathrm{Ni}$ : A review. J. Food Sci. 2014, 79, R765-R780, doi:10.1111/1750-3841.12433.

94. Demirezen, D.; Aksoy, A. Heavy metal levels in vegetables in Turkey are within safe limits for $\mathrm{Cu}, \mathrm{Zn}, \mathrm{Ni}$ and exceeded for $\mathrm{Cd}$ and $\mathrm{Pb}$. J. Food Qual. 2006, 29, 252-265, doi:10.1111/j.1745-4557.2006.00072.x.

95. Murtaza, G.; Ghafoor, A.; Qadir, M.; Owens, G.; Aziz, M.A.; Zia, M.H.; Saifullah. Disposal and use of sewage on agricultural lands in Pakistan: A review. Pedosphere 2010, 20, 23-34.

96. Jamil, M.; Zia, M.S.; Qasim, M. Contamination of agro-ecosystem and human health hazards from wastewater used for irrigation. J. Chem. Soc. Pak. 2010, 32, 370-378.

97. He, Z.L.L.; Yang, X.E.; Stoffella, P.J. Trace elements in agroecosystems and impacts on the environment. J. Trace Elem. Med. Biol. 2005, 19, 125-140, doi:10.1016/j.jtemb.2005.02.010.

98. Albering, H.J.; van Leusen, S.M.; Moonen, E.J.C.; Hoogewerff, J.A.; Kleinjans, J.C.S. Human health risk assessment: A case study involving heavy metal soil contamination after the flooding of the river Meuse during the winter of 1993-1994. Environ. Health Perspect. 1999, 107, 37-43.

99. Kramer, U. Metal hyperaccumulation in plants. Annu. Rev. Plant Biol. 2010, 61, 517-534, doi:10.1146/annurev-arplant-042809-112156.

100. Memon, A.R.; Schroder, P. Implications of metal accumulation mechanisms to phytoremediation. Environ. Sci. Pollut. Res. 2009, 16, 162-175, doi:10.1007/s11356-008-0079-z.

101. Salt, D.E.; Smith, R.D.; Raskin, I. Phytoremediation. Annu. Rev. Plant Physiol. Plant Mol. Biol. 1998, 49, 643-668, doi:10.1146/annurev.arplant.49.1.643.

102. Clemens, S. Toxic metal accumulation, responses to exposure and mechanisms of tolerance in plants. Biochimie 2006, 88, 1707-1719, doi:10.1016/j.biochi.2006.07.003.

103. Wei, S.; Anders, I.; Feller, U. Selective uptake, distribution, and redistribution of Cd-109, Co-57, Zn-65, Ni-63, and Cs-134 via xylem and phloem in the heavy metal hyperaccumulator Solanum nigrum L. Environ. Sci. Pollut. Res. 2014, 21, 7624-7630, doi:10.1007/s11356-014-2636-y.

104. Kupper, H.; Lombi, E.; Zhao, F.J.; McGrath, S.P. Cellular compartmentation of cadmium and zinc in relation to other elements in the hyperaccumulator Arabidopsis halleri. Planta 2000, 212, 75-84, doi:10.1007/s004250000366.

105. Kramer, U.; Chardonnens, A.N. The use of transgenic plants in the bioremediation of soils contaminated with trace elements. Appl. Microbiol. Biotechnol. 2001, 55, 661-672.

106. Ferraz, P.; Fidalgo, F.; Almeida, A.; Teixeira, J. Phytostabilization of nickel by the zinc and cadmium hyperaccumulator Solanum nigrum L. Are metallothioneins involved? Plant Physiol. Biochem. 2012, 57, 254-260, doi:10.1016/j.plaphy.2012.05.025. 
107. Rascio, N.; Navari-Izzo, F. Heavy metal hyperaccumulating plants: How and why do they do it? And what makes them so interesting? Plant Sci. 2011, 180, 169-181, doi:10.1016/j.plantsci.2010.08.016.

108. Pence, N.S.; Larsen, P.B.; Ebbs, S.D.; Letham, D.L.D.; Lasat, M.M.; Garvin, D.F.; Eide, D.; Kochian, L.V. The molecular physiology of heavy metal transport in the $\mathrm{Zn} / \mathrm{Cd}$ hyperaccumulator Thlaspi caerulescens. Proc. Natl. Acad. Sci. USA 2000, 97, 4956-4960, doi:10.1073/pnas.97.9.4956.

109. Yamaji, N.; Xia, J.X.; Mitani-Ueno, N.; Yokosho, K.; Ma, J.F. Preferential delivery of zinc to developing tissues in rice is mediated by P-type heavy metal ATPase OsHMA2. Plant Physiol. 2013, 162, 927-939, doi:10.1104/pp.113.216564.

110. Kobayashi, T.; Ita, R.N.; Nishizawa, N.K. Iron deficiency responses in rice roots. Rice 2014, 7, 27 , doi:10.1186/s12284-014-0027-0.

111. Colangelo, E.P.; Guerinot, M.L. Put the metal to the petal: Metal uptake and transport throughout plants. Curr. Opin. Plant Biol. 2006, 9, 322-330, doi:10.1016/j.pbi.2006.03.015.

112. Feller, U.; Vaseva, I.I. Extreme climatic events: Impacts of drought and high temperature on physiological processes in agronomically important plants. Front. Environ. Sci. 2014, 2, 39, doi:10.3389/fenvs.2014.00039.

113. Sharma, R.K.; Agrawal, M. Biological effects of heavy metals: An overview. J. Environ. Biol. 2005, 26, 301-313.

114. Welch, R.M.; Graham, R.D. Breeding crops for enhanced micronutrient content. Plant Soil 2002, 245, 205-214, doi:10.1023/A:1020668100330.

115. Yang, X.; Feng, Y.; He, Z.L.; Stoffella, P.J. Molecular mechanisms of heavy metal hyperaccumulation and phytoremediation. J. Trace Elem. Med. Biol. 2005, 18, 339-353, doi:10.1016/j.jtemb.2005.02.007.

(C) 2015 by the authors; licensee MDPI, Basel, Switzerland. This article is an open access article distributed under the terms and conditions of the Creative Commons Attribution license (http://creativecommons.org/licenses/by/4.0/). 